\title{
Fostering Communal Identities: Communitarian Artistic Projects in Local Communities of Premodern China
}

\author{
Junfu Wong \\ reywongji@hotmail.com \\ Wolfson College, University of Cambridge
}

To cite this paper: WONG, Junfu -Fostering Communal Identities: Communitarian Artistic Projects in Local Communities of Premodern China. Estudo Prévio 15. Lisboa: CEACT/UAL Centro de Estudos de Arquitetura, Cidade e Território da Universidade Autónoma de Lisboa, 2019. ISSN: 2182-4339 [Available at: www.estudoprevio.net]. DOI: https://doi.org/10.26619/2182-4339/15.1

Received on 2 February 2019 and accepted for publication on 25 May 2019.

Creative Commons, licence CC BY-4.0: https://creativecommons.org/licenses/by/4.0/

\begin{abstract}
China regional communities have a long history of fostering social interactions through artistic practices. During the fifth and sixth centuries, individuals in local communities were bonded to the greater collectives by participating in artistic projects of establishing stone stelae. Communal practices and liturgies were carried out around the stelae, that forged a platform enabling community members who belonged to different ethnic and social groups to collaborate. Both texts and icons inscribed on the stelae revealed a vivid picture of this artistic performance in local communities. By reviewing them, this paper reveals the ways this artistic practice of stele erection can help create the integrity of the community. It starts by setting out all the procedures required for establishing the stelae. It then unveils the symbolic function of the visual images on stelae that unified transcultural and transregional identities. Such an enquiry into the local communities in premodern period shows that art as a medium has a protracted history in unifying communities, reconciliating ethnic tensions, demarcating boundaries of identities and territories.
\end{abstract}

Keywords: China, Community, Art, Premodern, Identity 


\section{Introduction}

Communitarian projects around the globe often comprise a large scale of artistic practices, since artworks serve as powerful tool for symbolizing and demarcating territory and identity, together they form the foundation of the culture of a particular region. Former scholarship has approached this topic primarily from an anthropological perspective that generates fruitful reflection upon the modern communitarian artistic projects after the twentieth century. ${ }^{1}$ Nevertheless, this paper tends to bring in an example of the premodern period to enrich the discussion by proving that communitarian artistic projects also flourish in the past. Starting from the late fifth century, communities already showed a great tendency of using artistic projects to embody a set of functional concerns, such as unifying communities, reconciliating ethnic tensions among social groups, generating a communal identity that brought individuals into a broader collectivity. Chinese communities of premodern period are specifically introduced in this paper to broaden the discussion through a comparative lens of the east and the west. By adding such an oriental example into the scholarly discussion, it should be evident that communitarian art possesses a protracted transregional course rooted in different cultures that can be traced back in the premodern period.

China in the premodern period, especially during the timeframe adopted in this paper, the fifth and sixth centuries, was divided into the south and the north, both two regions experienced a compacted succession of kingdoms that were established by different ethnic tribes. ${ }^{2}$ Nomadic tribes entered the central plains around the early second century, established their kingdoms primarily through armed conquest. But soon this forceful act rebounded on the ruling reign as evidenced by a series of political rebellions. ${ }^{3}$ Seeing that force conquest failed to unify the kingdom, the court thus decided to learn from the previous dynasties by carrying out the sinification policy that forged ethnic connections through marriages. Such a policy required people from diversified foreign backgrounds to take up endemic surnames before joining local communities. It is this complicated political history of the northern plains led to a complex transethnic population in communities. Beginning in the late fifth century, a new type of religious community appeared in the northern regions, stretching along the western districts of the central plains. Guanzhong regions, serving as part of the capital districts in the late fifth and sixth centuries, became a fruitful land that accommodated these communities. Locating in suburban areas of the region, these communities served as local associations for lay people led by religious professionals, forming structuralized organization through a specific division of duties. Notably, these lay people, at least a large proportion of them, were by no means illiterates but educated squires. Some of them even served as governmental officials, coming from a privileged family tradition that gained them certain insight into political decisions.

But probably the utmost appealing fact is that these lay patrons were not connected by consanguinity, as they did not belong to the same clan. Rather, the great diversity shown in their surnames in fact attested that they belonged to totally different familial clans, coming from diverged societal and political backgrounds. It was even more 
surprising as some of these patrons came from a broad array of ethnic groups that entered the central plains at the beginning of the fourth century to settle down after military activities. ${ }^{4}$ But despite the differences between them, these lay patrons somehow performed a great conformity by establishing their communities through collaborations. Perhaps it is partly because of geographical coincidence that enabled them to form these communities as their families located adjacent to each other. ${ }^{5}$ Perhaps it is partly because of political regulations carried out during the late fifth century that laid the foundation of these communities. ${ }^{6}$ Building upon these former discussions, this paper aspires to add an artistic dimension into the discussion by contending that it was the activity of art that formed a public sphere allowing them to collaborate and congregate as organized communities.

During this period, lay patrons in these communities were bonded to the greater collectives by participating in communal artistic projects of establishing stone stelae for religious purposes. ${ }^{7}$ Erected in the middle of major crossroads, these stone stelae served as the center of the communities, projecting a sense of identity and territory of the adherent patrons. During important liturgical dates, lay patrons gather in front of the stele to participate consecratory activities by taking up different duties. Corresponding areas demarcated by the stele became a crucial sphere of social interactions in the local communities as they were the place where major communal events took place.

Zooming into the artistic perspective of the stelae, engraved on them were texts and icons that expressed the religious motivations and aspirations of the lay patrons. Not only native auspicious symbols but also those that expressed the disparity in terms of ethnicity were depicted on the stone stelae. Following this premise, the artistic practice of stele erection was significant as it created a platform that allowed community members to collaborate and congregate, thus creating the integrity of the community, unifying ethnic tribes by allocating them into a broader societal framework. It is within this context that this paper attempts to reveal the ways this artistic practice of stele erection can help create the integrity of the community. It starts by examining the procedures engaged in the project of stele erection to unveil their function in creating a platform for the collaborations of the lay adherents. It then proceeds to discuss the emblems on stelae from a functional perspective to explore their artistic symbolic connotation in creating and unifying transcultural and transregional ethnic identities. Such an artistic enquiry into the stele projects should reveal both the artistic concerns and practices of the lay patrons in the late fifth and sixth centuries. It shows that art as a powerful device to generate identity bears a protracted function of unifying communities, evoking a sense of collectivity, reconciliating ethnic conflicts caused by cultural differences. By remarking on the shared genealogy of art practices across regional and temporal boundaries, both in the east and the west, this paper concludes by readdressing the similarities behind the practice of establishing artistic projects in communities. Namely two approaches are adopted in this paper to examine both texts and icons on stelae. Pertinently speaking, the first part of the paper is built upon a detailed textual analysis of stele inscriptions to provide a basic sketch of the art projects carried out in local communities. Selected excerptions are presented to show the procedures taken for establishing stone stelae. Iconographical approach is also 
adopted to complicate the discussion by identifying the artistic symbols on stelae before exploring their functions. It responds to a broader genealogy of artistic representation through a comparative lens that traced the possible provenance of the symbols.

\section{Art Project in Premodern Local Communities}

During the late fifth and sixth centuries, a new type of religious communities appeared in the northern regions. Lay people from different cultural and familial backgrounds dwelled in the same community, sharing a same recognition of territory due to geographical proximity. ${ }^{8}$ Comprising primarily lay people but sometimes joined by regional governors, these communities followed a strict hierarchical order, probably ranked by importance, that divided the patrons into several groups in charge of different duties. ${ }^{9}$

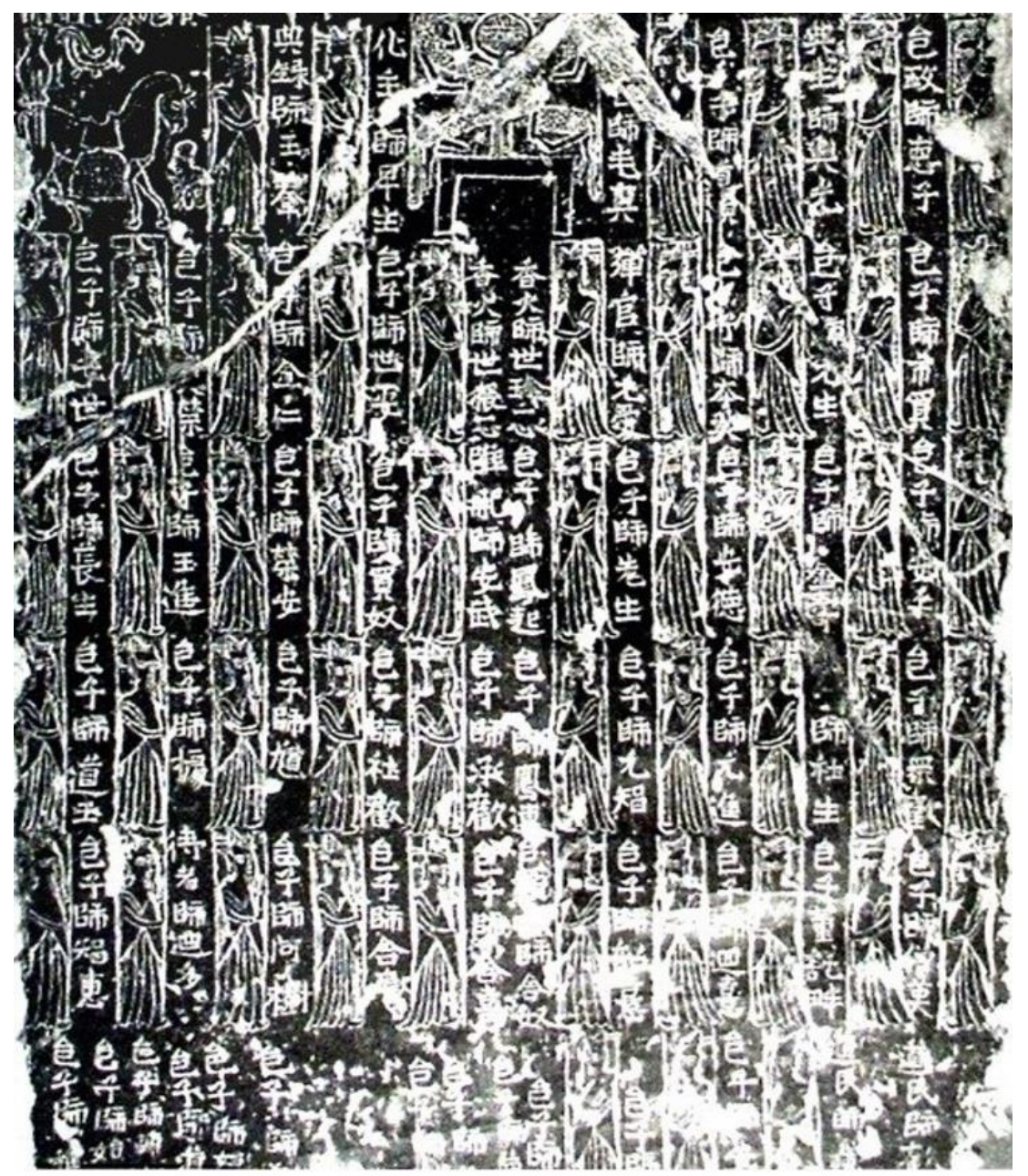

Image 1 - Plate 1 Shi Zhenxing Stele, 師真興造像碑, 523 CE, Back face of the stele. 


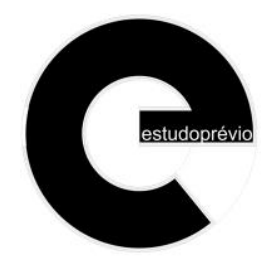

P02 | EP15 | s2019

Evident in the figure is a patronage name list, accompanied by the depiction of the patrons on the side, that recorded all the patrons committing to the activity of stele erection in communities. Listed at the topmost was those community leaders, probably those senior elites of the community, that partly labelled themselves as officials of the communities, partly registered themselves as religious professionals. ${ }^{10}$ Below the first role, all the remaining patrons simply referred themselves as the members of the community, of whom no specific position was taken. ${ }^{11}$ Led by the senior elites, lay people usually engaged in communal artistic project of establishing stone stelae for religious purposes. Such an artistic project was often known as the establishment of a statue or a shrine, although the artefact created actually took up the form as stone tablets that contained four sides, each side carved with sophisticated icons and texts:

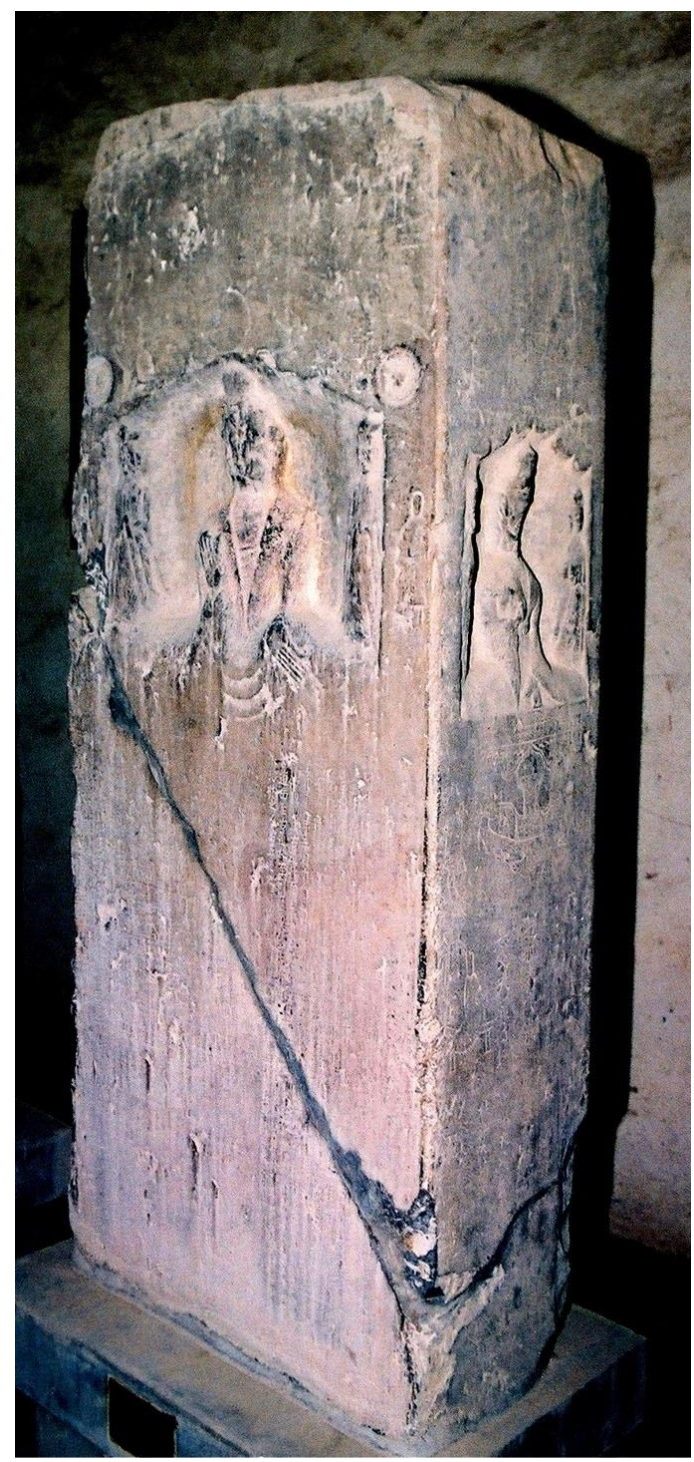

Image 2 - Plate 2 Fumeng Wenqing Stele, 夫蒙文慶造像碑, 519 CE, Front face of the stele. 
Fumeng clan serving as the principle patronage group in the community built this stele on behalf of the community to pray for their deceased ancestors through consecrating the religious deities enshrined on the stele. Normally, the process of stele erection comprised several procedures, starting by preparing the fund required to employ craftsman to carve the stone:

\author{
七世父母，因緣脊屬，造立石像一區，減割家珍，雇請良匠。(《夫蒙文慶造像碑》) \\ For the deceased seven generations of ancestors, for all clan relatives of all \\ serendipities, to establish this one stone statue, diminish the family treasures, \\ employ skillful craftsman (Fumeng Wenqing Stele) ${ }^{12}$
}

Some less prosperous communities would try to complete this procedure by asking each clan in the community to donate. Patrons of the communities would prepare the sum by reducing expenditure, a practice that usually exaggerated as complete exhaustion of their property. Soon after collecting the fund, a stone was then prepared to be carved:

\title{
各自竭家珍，故刊石造形像一軀。(《張乾度造像碑》) \\ Each of us uses up our family treasures, thus carve on the stone to establish one statue. (Zhang Qiandu Stele) $)^{13}$
}

Nevertheless, the craft practice was not done by the patrons but professional craftsman. ${ }^{14}$ Such a preparation process was captured even more detailed on another stele. It recorded that lay patrons devoted a great effort to find the appropriate stone after sufficient funds. Following that was to appoint a craftsman to establish the stele:

減割七珍，遠取名石，延及師匠，造像一軀。(《魏道節造像碑》)

Diminish the seven treasures, reaching so far to obtain the best stone, further hiring craftsman, to establish one statue. (Wei Daojie Stele) $)^{15}$

Finally, the stele was completed and positioned at the middle of the major crossroad of the community. ${ }^{16}$ Some community keened to further build an exquisite shed to accommodate the stele, consecrating it by religious offerings:

\section{造千佛石像一軀，四面細好銘一軀，精舍一軀，侍雜果七十餘種。(《晏僧定造像碑》) \\ Build one stone statue of the thousand buddhas, one tablet that contained four sides of sophisticated epigraphs, one exquisite shed, using seventy kinds of mixed fruits to consecrate them. (Yan Zengding Stele) ${ }^{17}$}

During significant liturgical dates, religious activities were carried out in front of the stele, which created a platform that unified the community members again. ${ }^{18}$ But apart from that, social activities would also take place around the stele. Community members who belonged to different ethnic groups would gather to attend some entertainments. For example, acrobatic performance, probably a popular choice for lay people during that period of time, took place in front of the stele. 


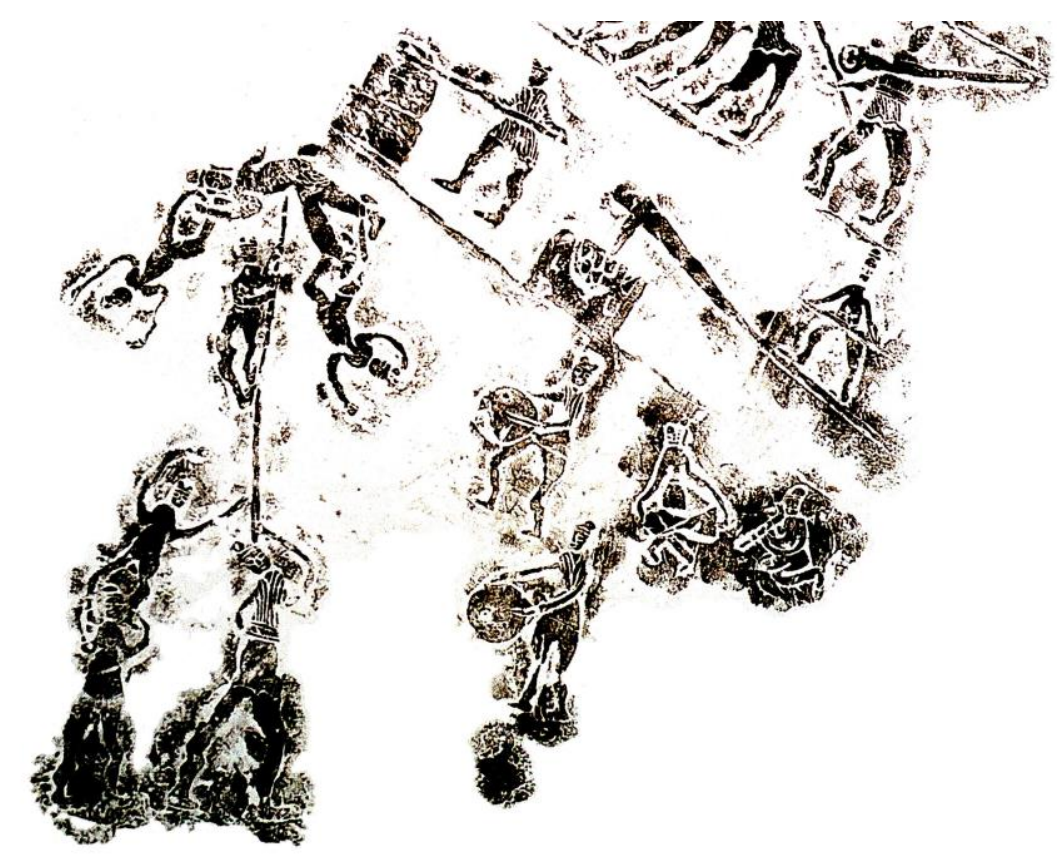

Image 3 - Plate 3 Lifei Fusheng Stele, 荔非伏生造像碑, 508-534 CE, Back face of the stele.

Captured on this stele were some of the scenes of lay entertainments. ${ }^{19}$ Pivoting on top of a wooden pillar, some acrobatic performer was performing difficult bodily gyrations. Perpendicular to the scene of acrobatic performance, two figures were playing the drums as part of the festival fringe. Likewise, another figure was sitting on his knee, playing a flute as another accompanying figure seemed to be performing certain bodily performance.

From the above discussion, it is evident that lay people from different sibship and kinship background were joined together by participating in the art project of establishing stone stelae in the local communities. Given the ethnic diversified nature of these lay patrons, the communal art project became even more appealing as it provoked a connection between aesthetics and ethnicities. Communitarian artistic practice became a key in reconciliating ethnic tensions as it generated a shared platform that allowed patrons from different ethnicity to form an artefact that represented them as a collective. Former scholarship has related the state of ethnic amalgamation to the political success of the ruling reign. Sinicization that took place in the late fifth century partly contributed to this state, as it allowed them to accommodate into the native culture at a policy level. Nevertheless, by zooming at the practical level, this paper attempts to argue that it is the art project that unified these patrons. Such a statement will be further elaborated in the next section which focused on the artistic symbols carved on the stone stelae. 


\section{Artistic Symbolization of Communal Identities}

Dedicated by lay patrons, these stone stelae embodied impressive artistic symbols that expressed the aesthetic perception of the lay patrons in depicting their ideology. Despite some paltry artistic disparities and diversities in terms of portraying symbols among the communities that attested to regional differences, this paper addresses those commonly depicted symbols on the stelae.

Native symbols of great auspicious significance were installed on stone stelae to project the sacred realm. Chinese dragons, for example, the legendary creatures that traditionally symbolize auspicious potent served also as typical symbols on stone stelae. During the late antiquity, around the first century, dragon could be found in tomb arts that suggested a path of becoming deities. ${ }^{20}$ Capable of flying in the sky, dragon possessed the power of travelling between spiritual realms, connecting them by serving as the transportation. Deceased ancestors could then ride on a dragon that escorted them to the front of the heavenly gate. But the dragon depicted on stone stelae was presented in a slightly different way, as it became the rooftop of the shrine engraved on the stelae, rather than simply an auspicious creature that guided the deceased to the celestial realm.

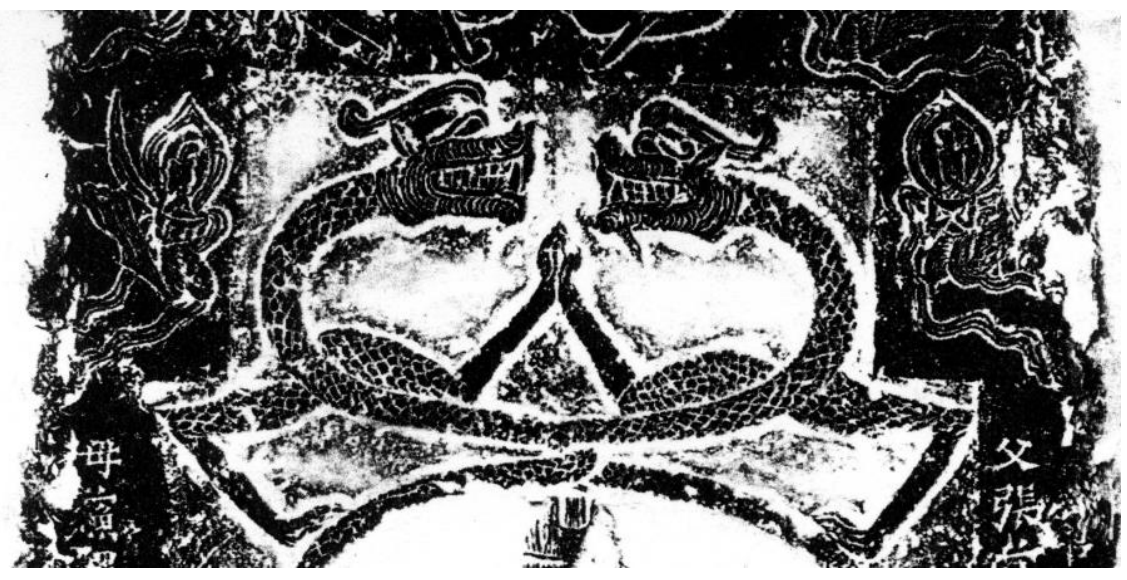

Image 4 - Plate 4 Zhang Luanguo Stele, 張亂國造像碑, 514 CE, Back face of the stele.

By gazing at each other, the two dragons formed a perfect symmetrical ellipse, joining one of their hands together, leaving the other touching upon the rooftop that was depicted in the form of a dragon as well. Probably, this pair of dragons symbolized the unison of the universe by joining to form the gate of the celestial realm.

Likewise, tiger also served as gate guardian starting from the late antiquity:

言天門凡有九重，使神虎豹執其關閉。

It is said that the heavenly gate has nine layers, each of them is guarded by a celestial tiger that takes responsibility to ensure the gate is closed. ${ }^{21}$ 
But tiger served for a more multidimensional iconographical purpose on stelae. Put in pairs in front of a compound, these tigers symbolized the guardian of the community, protecting religious rites against evil spirits through carrying of religious censers.

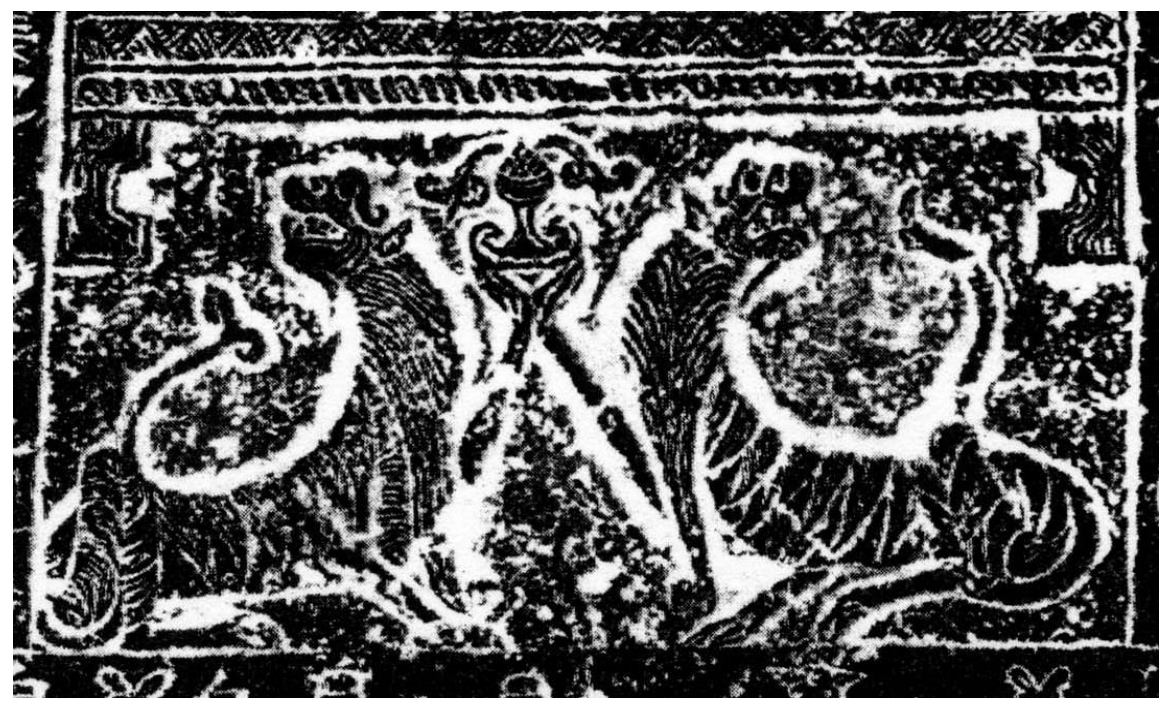

Image 5 - Plate 5 Zhang Luanguo Stele, 張亂國造像碑, 514 CE, Back face of the stele.

Bending their bodies, the two tigers extended their paws to hold a small censer, a common ritual vessel used in liturgies for burning incense. Birds also comprised a great proportion to the symbolic system of stone stelae. Putting in pairs, the birds stood on the rooftop of the shrine, carrying a certain kind of grass in their beak.

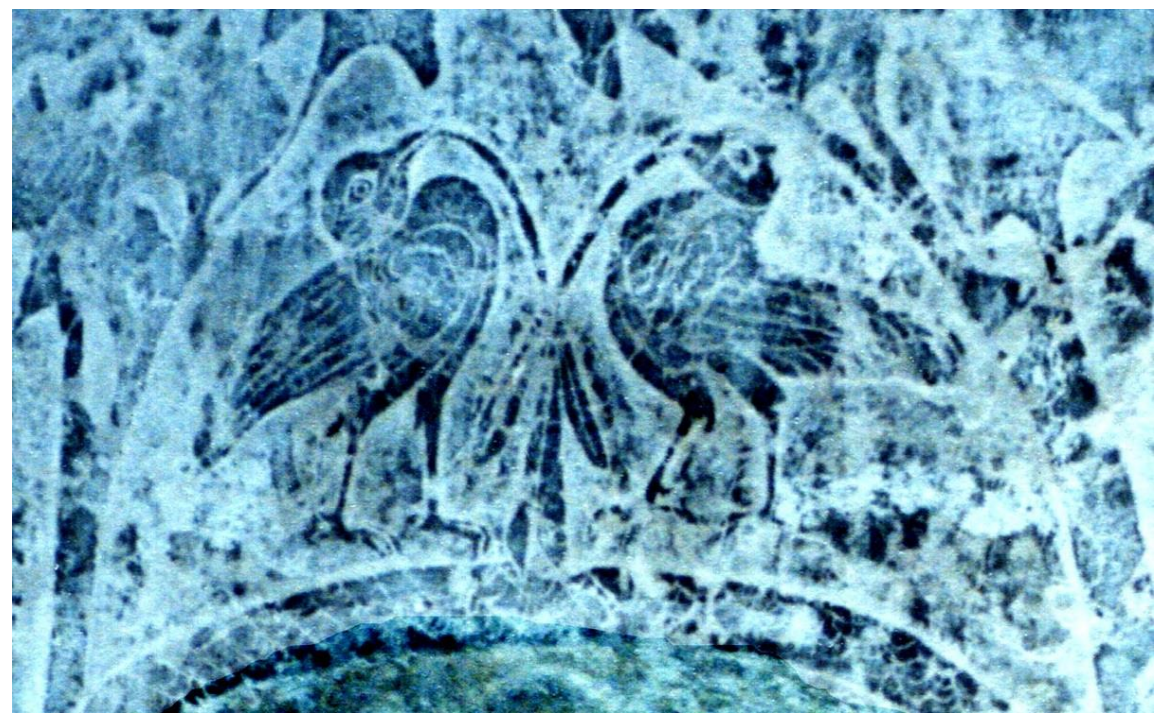

Image 6 - Plate 6 Qi shuanghu Stele, 錡雙胡造像碑, 520 CE, Back face of the stele. 
By tracing into the literary trajectory, scholars tended to regard this bird as a special kind of bird that carried immortal grass from a remote celestial island:

\section{多枉死者橫道，有鳥如烏狀，銜此草覆死人面，當時起坐而自活也。 \\ Erstwhile, there was a large number of deceased bodies who died of being wronged littering along the road. Some raven-like birds passed by, carrying this grass in their beak to cover the face of the deceased. Just at that moment, the deceased sat up, came alive again. ${ }^{22}$}

Depicted on the stelae, this pair of birds symbolized the presence of a celestial land probably used to accommodate the deceased ancestors.

Finally, deer being privileged as an auspicious symbol of longevity in the late antiquity also appeared on stone stelae. ${ }^{23}$ Depicted on the stele was a sika deer, joined by a tiger, gazing at the shrine. Former scholars tended to translate this set of symbols together by labelling it as a chasing scene. ${ }^{24}$ But this argument underestimated the symbolic function of the deer by large. Probably the deer on the stele symbolized the search for longevity that led to celestial land.

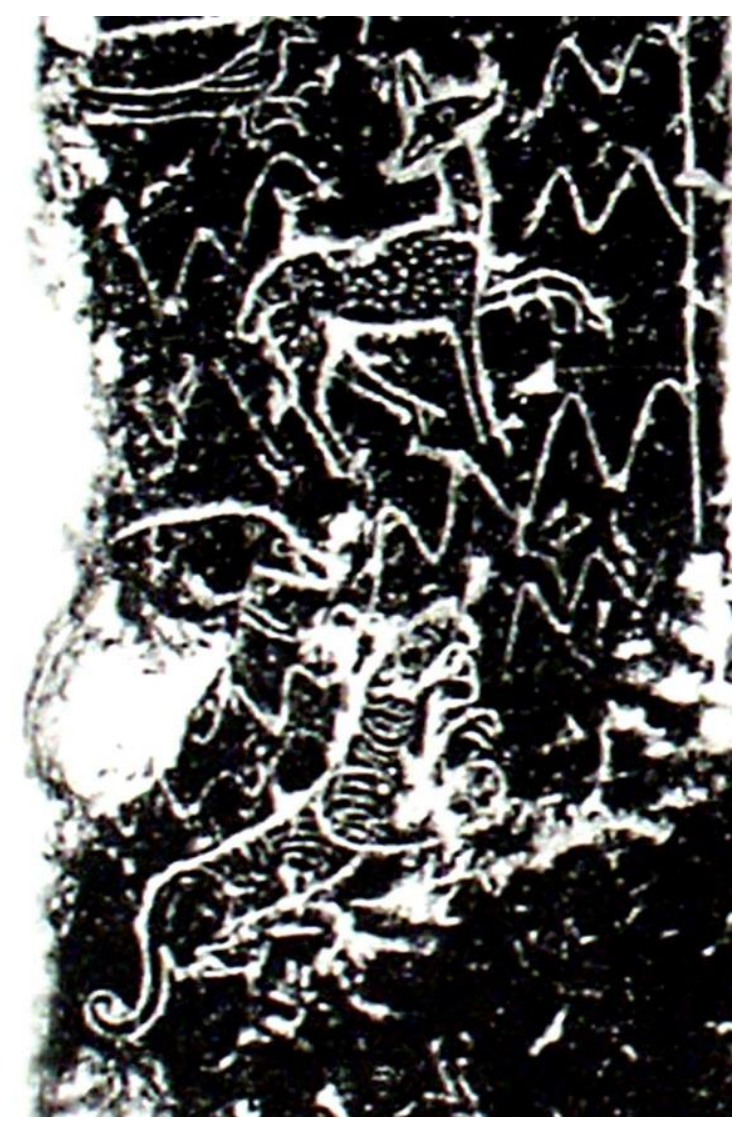

Image 7 - Plate 7 Wei Wenlang Stele, 魏文朗造像碑, 424 CE, Back face of the stele. 
It should also be emphasized that these four animals were not depicted by random choice but represented the four cardinal points in the ancient geomancy and cosmology. ${ }^{25}$ Even though this cardinal system became less effective during the fifth century, the four animals remained as efficacious and auspicious symbols in the regional beliefs of lay people.

Furthermore, apart from native symbols, there were foreign symbols engraved on the stelae that demonstrated the practice of transregional and transcultural adaptation. Former scholarship has recognized this fact by pointing out that the nomadic patrons in these communities contributed largely to the creation of artistic images by designing appropriate emblems to represent themselves. ${ }^{26}$ Significantly, the horse image shown on the stelae pointed specifically to the nomadic people as they had a protracted history of riding on horses to flight and battle. ${ }^{27}$ But it does not necessarily mean that the horse was a foreign animal totally unseen in the central plains before the late fifth century. Creel argued that there were three phases in the employment of the horse for transportation. ${ }^{28}$ Shang (1765-1123 BC) people, for example, already started to domesticate horses for the purpose of pulling chariot. Earliest was the use of horse for traction, such as pulling the chariots. It then began to be used as a means of transportation. Finally, it was further developed as a charger of war. It is this final phrase that gave rise to the prevalence of the horse image on stone stelae. Nomadic people aspired to depict themselves as horse riders as this practice represented strength.

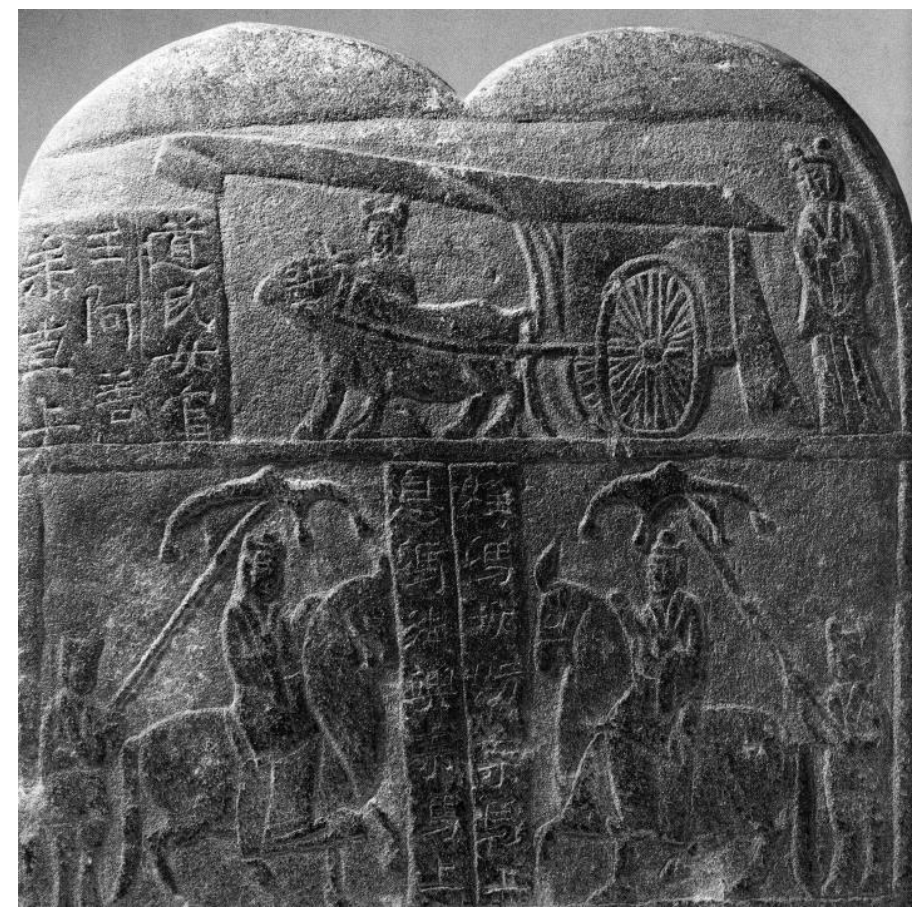

Image 8 - Plate 8 Wang Ashan Stele, 王阿善造像碑, 527 CE, Back face of the stele. 
Religious symbols, just as religious belief itself, served as crucial elements that unified lay adherents from various ethnic backgrounds. Buddhism, as a foreign religion that had successfully been transplanted in the native culture, presented a brilliant example of accommodating foreign elements on the native soil. ${ }^{29}$ Nomadic people, in particular, showed great respect of this religion as evident by their adoption of the religion at the level of statecraft. ${ }^{30}$ Gandhanra, an ambisextrous spirit in the religion specialized in musical instruments, was depicted on some stelae as a remarkable emblem of celestial realm. ${ }^{31}$

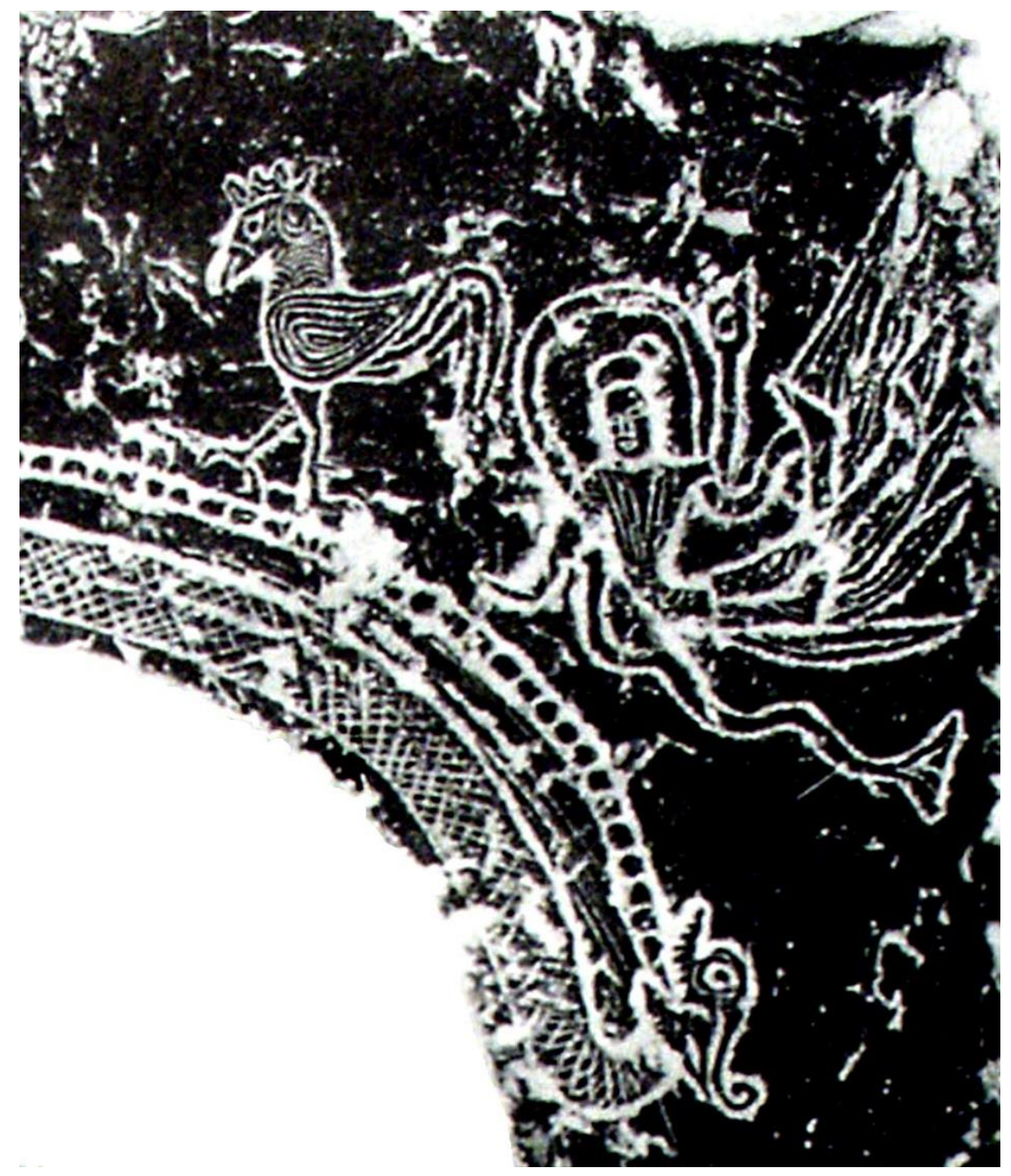

Image 9 - Plate 9 Wei Wenlang Stele, 魏文朗造像碑, 424 CE, Back face of the stele.

By playing musical instruments, this godly figure put forward a sense of general tranquility of the community. 
By embodying all these artistic symbols, the stelae became a symbolic platform that accommodated all diversified ethnic cultures in the communities, through which to figuratively unify all ethnic groups into one consolidated transethnic collective, despite their diversity in terms of cultural or societal background.

\section{Conclusion}

During the late fifth and sixth centuries, lay members of local communities devoted themselves to communal artistic projects of establishing stone stelae to embody their religious concerns. During this process, the group of principal patrons would start by asking for financial sponsorship from all community members, then proceeded to select a stone for an appointed craftsman to carve a stele out of it upon request. It produced the first opportunity for community members to collaborate throughout the preparation period. Soon after the stele was finished, it would be placed in the middle of major crossroads in the communities, serving as a central monument that demarcated the boundaries of territory and identity for relevant community members. During major religious dates, consecratory activities would take place around the stele, an event that allowed all community members to collaborate again. Lay patrons would also gather in front of the stele for communal social activities such as acrobatic performances. By considering these premises, it is articulated that the artistic project of stele erection fostered the social interactions among the community members, creating a platform that allowed people from distinctive ethic background to collaborate, an act that eventually reconciliated ethnic tensions in a regional context. Furthermore, lay people employed artistic symbols to creating and unifying identities throughout history. Belonging to different ethnic culture, these symbols became significant representation of regionality that formed ethnic identity. Lay people in local communities tried to group them together on stelae to further the agenda of unifying all ethnic tribes.

Due to the urbanization project of the twentieth century, this type of local communities no longer preserved in the region. Lay people also abandoned the act of erecting stelae to represent their religious belief. Nevertheless, the artistic symbols that once appeared on stone stelae still remain powerful in the region. It should be obvious that communitarian artistic project did not stem from modernity. Chinese, among all other great civilizations, already carried out similar activities in the premodern period to gather community members. It should also be attested that art as a medium has a long history in unifying communities, reconciliating ethnic tensions, creating a sense of identity and territory that portrayed the social milieu of its time. 


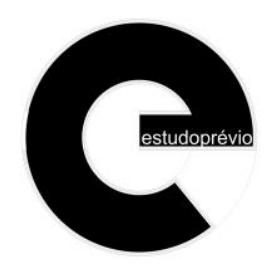

P02 | EP15 | s2019

\section{Bibliography:}

\section{Primary Sources}

[Warring States 戰國] Qu Yuan 屈原. Songs of Chua 楚辭. Beijing: Chung Hwa Book Company, 2013.

[Western Han 西漢] Dongfang Shuo 東方朔. Records of Ten Islands of the Inner Sea 海內十洲 記, Daozang 道藏. Vol. 11. Beijing: Wenwu Press, 1998.

\section{Secondary Sources}

ABE, Stanley - Ordinary Images. London: The University of Chicago Press, 2002. ISBN 978-022600-0442.

BARFIELD, Thomas - The Perilous Frontier: Nomadic Empires and China. Cambridge: Basil Blackwell, 1989. ISBN 978-1-55786-3249.

CHEN, Huaiyu - Transforming Beasts and Engaging with Local Communities: Tiger Violence in Medieval Chinese Buddhism. Pakisan Journal of Historical Studies. Vol. 3, no. 1 (2018), p. 31-60. ISBN 2412-611X.

CHEN, Yinque 陳寅恪 - Wei jin nanbeichao yanjianglu 魏晉南北朝史講演錄. Taipei: Yunlong Press, 1995. ISBN 978-98663-441-3-8.

CONSTEN, Eleanor - The Deer in Early Chinese Art. Artibus Asiae. Vol. 26, no/ 3/4 (1963), p. 191-206. ISBN 0004-3648.

CREEL, Herrlee - The Role of the Horse in Chinese History. The American Historical Review. Vol. 70, no. 3 (1965), p. 647-672. ISBN 0002-8762.

CREHAN, Kate - Community Art: An Anthropological Perspective. London: Berg, 2011. ISBN 978-0-86785-3165.

FLOOD, Gavin - An Introduction to Hinduism. Cambridge: Cambridge University Press, 1996. ISBN 978-0-52143-8780.

GAO, Xia 高峽 - Xian beilin quanji 西安碑林全集. Guangdong: Guangdong Economic Press, 1999. ISBN 978-78063-261-6-9.

HAN, Lizhou 韓理州 - Quan beiwei dongwei xiwei wen buyi 全北魏東魏西魏文補遺. Shaanxi: Sanqin Publishing, 2010. ISBN 978-78073-645-1-1.

HOU, Xudong 侯旭東 - Beichao cunmin de shenghuo shijie 北朝村民的生活世界. Beijing: China Social Sciences Press, 1998. ISBN 978-71000-449-3-6.

HOU, Xudong 侯旭東 - Wu liu shiji beifang minzhong fojiao xinyang 五六世紀北方民眾佛教信仰. Beijing: Social Sciences Academic Press, 2005. ISBN 978-75004-227-8-5.

HU, Wenhe 胡文和 - Zhongguo daojiao shike yishushi 中國道教石刻藝術史. Beijing: Higher Education Press, 2004. ISBN 978-70401-390-8-2.

JUROSZ, Gabriela - Anthropology of Art: Indigenous Concepts in Contemporary Art in Guatemala. Anthropos. ISBN 0257-9774. Vol. 109, no. 1 (2014), p. 206-217.

KLEEMAN, Terry - Celestial Masters: History and Ritual in Early Daoist Communities. Cambridge: Harvard University Asia Center, 2016. ISBN 978-0-67473-7167.

LATTIMORE, Owen - Inner Asian Frontiers of China. Boston: Beacon Press, 1962. ISBN 9780-19582-7811.

LI, Ping 李憑 - Bei wei pingcheng shidai 北魏平城時代. Shanghai: Shanghai Guji Press, 2014. ISBN 978-75325-735-5-4.

LI, Song 李淞 - Chang'an yishu yu zongjiao wenming 長安藝術與宗教文明. Beijing: Chunghwa Book Company, 2002. ISBN 978-71010-363-1-2.

LI, Song 李淞 - Shaanxi gudai fojiao yishu 陝西古代佛教藝術. Shaanxi: Shaanxi Renmin Jiaoyu Press, 2000. ISBN 978-75419-776-3-3. 
LUO, Hongcai 羅宏才 - Zhongguo fodao zaoxiangbei yanjiu, yi guanzhong diqu wei kaocha zhongxin 中國佛道造像碑研究: 以關中地區為考察中心. Shanghai: Shanghai University Press, 2008. ISBN 978-78111-837-8-8.

MA, Changshou 馬長壽 - Beiming suojian qian qin zhi suichu de guanzhong buzu 碑銘所見前秦 至隋初的關中部族. Guilin: Guangxi Normal University Press, 2006. ISBN 978-75633-604-99.

MOLLIER, Christine - Buddhism and Taoism Face to Face: Scripture, Ritual, and Iconographic Exchange in Medieval China. Honolulu: University of Hawaii Press, 2009. ISBN 978-082483-4111.

OLSEN, Stanley - The Early Domestication of the Horse in North China. Archaeology. Vol.37, no. 1 (1984), p. 62-63. ISBN 0003-8113.

OLSEN, Stanley - The Horse in Ancient China and Its Cultural Influence in Some Other Areas. Proceedings of the Academy of Natural Sciences of Philadelphia. Vol. 140, no. 2 (1988), p. 151-189. ISBN 0097-3157.

PUETT, Michael - To Become a God: Cosmology, Sacrifice and Self-Divinization in Early China. Cambridge: Harvard University Press, 2002. ISBN 978-0-67401-6439.

RAZ, Gil - The Emergence of Daoism: Creation of Tradition. New York: Routledge, 2012. ISBN 978-0-415-77849-7.

STECHER, Annette de - The Art of Community. Canadian Art Review. ISBN 0315-9906. Vol. 42, no. 2 (2017), p. 54-71.

TSENG, Lillian - Funerary Spatiality: Wang Hui Sarcophagus in Han China. Anthropology and Aesthetics. No. 61/62 (2012), p. 116-131.

WANG, Xiaoyang 汪小洋 - Meishu kaogu yu zongjiao meishu 美術考古與宗教美術. Shanghai: Shanghai University Press, 2008. ISBN 978-78111-837-4-0.

WATT, James - The Giraffe as the Mythical Qilin in Chinese Art: A Painting and a Rank Badge in the Metropolitan Museum. Metropolitan Museum Journal. Vol. 43 (2008), p.111-115. ISBN 0077-8958.

WEl, Hongli 魏宏利 - Bei wei guanzhong diqu zaoxiangji 北魏關中地區造像記. Beijing: China Social Science Press, 2017. ISBN 978-75161-929-0-0.

WILSON, Keith - Powerful Form and Potent Symbol: The Dragon in Asia. The Bulletin of the Cleveland Museum of Art. Vol. 77, no. 8 (1990), p. 286-323. ISBN 0009-8841.

WONG, Dorothy - Chinese Steles: Pre-Buddhist and Buddhist Use of a Symbolic Form. Honolulu: University of Hawaii Press, 2004. ISBN 13: 978-0-82482-7830

YAO, Weiyuan 姚薇元 - Beichao huxing kao 北朝胡姓考. Wuhan: Wuhan University Press, 2013. ISBN 978-71010-282-9-4.

ZHANG, Peng 張鵬 - Beichao shike wenxian de wenxue yanjiu 北朝石刻文獻的文學研究. Beijing: China Social Science Press, 2015. ISBN 978-75161-623-8-5

ZHANG, Zexun 張澤珣 - Bei wei guanzhong daojiao zaoxiangji yanjiu 北魏關中道教造像記研究. Macau: Macau University Press, 2009. ISBN 978-99937-943-7-0.

ZHAO, Chao 趙超 - Zhongguo gudai shike gailun 中國古代石刻概論. Beijing: Cultural Relics Publishing House, 1997. ISBN 978-75-01-00927-5.

ZHAO, Qiguang - Chinese Mythology in the Context of Hydraulic Society. Asian Folklore Studies. Vol.48, no.2 (1989), p. 231-246. ISBN 0385-2342.

ZÜRCHER, Erik - The Buddhist Conquest of China. Leiden: Brill, 2007. ISBN 978-90-47-419426. 


\section{Biographical note}

Junfu Wong is currently a PhD student in the Faculty of Asian and Middle Eastern Studies, University of Cambridge. He received his MA degree in the Department of Religions and Philosophies, SOAS, University of London. Specializing in Comparative Religion of Buddhist and Daoism, his research seeks to explore the complex interplay of the twin religions in medieval China by using epigraphical inscriptions. He also holds a research interest in the cultural interaction of China with its neighbors along the Silk Road.

\footnotetext{
${ }^{1}$ Kate Crehan (2013) did a detailed study that encompassed a broad regional diversity to explore key issues of community art shared by these communities from an anthropological perspective. By selecting convincing case studies to demonstrate the artistic practice of communities after the twentieth century, she sharply underlined the significance of these artistic projects in responding to local needs. See Kate Crehan. Community Art: An Anthropological Perspective. London: Berg (2011). Gabriela Jurosz (2014) explored the connotation of indigenous concepts used in contemporary art by using a regional example to project a global perspective. See Gabriela Jurosz. Anthropology of Art: Indigenous Concepts in Contemporary Art in Guatemala. Anthropos. Vol. 109, no. 1 (2014), p. 206-217. Annette de Stecher (2017) prepared an exploration that led us to reconsider the process of identity making through art performances, such as embroidery, that demonstrated a continuity between different periods of indigenous art history. See Annette de Stecher. The Art of Community. Canadian Art Review. Vol. 42, no. 2 (2017), p. 54-71.

2 During the late fifth and sixth centuries, there were in total six dynasties successively in control of the central plains. Chen (1985) presented one of the earliest study of the political and societal upheavals during this period. See Chen Yinque 陳寅恪. Wei jin nanbeichao yanjianglu 魏晉南北朝史講演錄. Taipei: Yunlong Press (1995).

3 Local clans, though appearing to have yielded to the regime, remained psychologically unwilling to obey under the rule of ethnic tribes. Numerous rebellions triggered by the antagonistic position of regional suzerains, as recorded in the official documents, took place during the late fifth and sixth centuries. Li Ping 李憑 (2014) gave a brilliant account on this complicated period by revealing the factional and regional conflicts that finally led to the fall of the ethnic kingdoms. See Li Ping 李憑. Bei wei pingcheng shidai 北魏平城時代. Shanghai: Shanghai Guji Press (2014).

${ }^{4}$ Ma Changshou 馬長壽 (2006) traced the migration trajectory of the ethnic tribes that prepared the later flourish of these groups in local communities. See Ma Changshou 馬長壽. Beiming suojian qianqin zhi suichu de guangzhong buzu 碑銘所見前秦至隋初的關中部族. Guilin: Guangxi Normal University Press (2006).

${ }^{5}$ Hou Xudong 侯旭東 (1998) in his study reviewed the geographical distributions of the communities. See Hou Xudong 侯旭東. Beichao cunmin de shenghuoshijie 北朝村民的生活世 界一朝廷、州縣與村里. Beijing: Commercial Press (1998). Zhang Zexun 張澤珣 (2009) created a typographical map in her work that pinpointed the place of stele erection in an attempt to prove the geographical proximity of these communities. See Zhang Zexun 張澤珣. Beiwei guanzhong daojiao zaoxiangji yanjiu 北魏關中道教造像記研究. Macau: Macau University Press (2009), p. 139.
} 
${ }^{6}$ Li Ping 李憑 (2014) conducted a detailed analysis of the political policies carried out during the fifth and sixth centuries. See Li Ping 李憑. Bei wei pingcheng shidai 北魏平城時代. Shanghai: Shanghai Guji Press (2014).

${ }^{7}$ For discussion on stone stelae, there are several contributions in previous scholarship. Ma Changshou 馬長壽 (2006) conducted a foundation work in pointing out that the stele communities were not entirely constituted by local (Han 漢) people but also foreign people (Non-Han 非漢人). See Ma Changshou 馬長壽. Beiming suojian qianqin zhi suichu de guangzhong buzu 碑銘所見前秦至隋初的關中部族. Guilin: Guangxi Normal University Press (2006). Dorothy C. Wong (2004) traced the trajectory of the variation of the symbolic forms of stone stelae from ancient time to modern, by indicating that there was a watershed on the symbolic structure of stelae after the introduction of Buddhism. She discussed briefly on the artistic style of stone stelae in the Northern Wei, but remained on a descriptive level. Her major contribution was to define the artistic style of stone stelae in a regional context. See Dorothy $\mathrm{C}$. Wong. Chinese Steles: Pre-Buddhist and Buddhist Use of a Symbolic Form. Honolulu: University of Hawaii Press (2004). Luo Hongcai 羅宏才 (2008) studied the iconic elements of the Buddhist-Daoist stone stelae from an archeological perspective. His major contribution was to link the erection of stelae with the influence of other cultures along the silk road according to ethical diversity of the patrons revealed in many stele inscriptions. But what he neglected was how exactly these stelae were used and performed in ritual activities. See Luo Hongcai 羅宏才. Zhongguo fodao zaoxiangbei yanjiu 中國佛道造像碑研究. Shanghai: Shanghai University Press (2008). Zhang Zexun 張澤珣 (2009) proposed a fundamental study on the Daoist elements on stone stelae by resonating the stele inscriptions with visual images. Her major contribution was to point out that the stelae were actually likened to altars for the patrons in the context of ritual performance. See Zhang Zexun 張澤珣. Beiwei guanzhong daojiao zaoxiangji yanjiu 北魏關中 道教造像記研究. Macau: Macau University Press (2009). See also Hou Xudong 侯旭東. Beichao cunmin de shenghuoshijie 北朝村民的生活世界一朝廷、州縣與村里. Beijing: Commercial Press (1998). Wei Hongli 魏宏利 (2017) in his most recent work collated and reviewed the stele inscriptions of the Northern Wei. His major contribution was to create an informative catalogue for further studies, but lack of coherent interpretation. See Wei Hongli 魏 宏利. Beichao guanzhong diqu zaoxiangji 北朝關中地區造像記. Beijing: China Social Science Press (2017).

${ }^{8}$ Such a topic on the ethnic diversity of the local communities has been remarked by scholars but still lack of thorough analysis so far. During the late fifth century, the process of sinicization requested people from ethnic tribes to take up native surname, dwelling in local communities in order to assimilate into the culture of the central plains. Serving as a direct result of that, the local communities became so ethnically diversified as can be exemplified by the patronage name list carved on the stone stelae. Ma Changshou 馬長壽 (1985) provided one of the earliest preliminary study on the ethnicity in the local communities by tracing the provenance of the surnames of the community members. See See Ma Changshou 馬長壽. Beiming suojian qian qin zhi suichu de guanzhong buzu 碑銘所見前秦至隋初的關中部族. Guilin: Guangxi Normal University Press (2006). Yao Weiyuan 姚薇元 (2013) furthered the discussion by giving a detailed survey on the surname during this period, especially focusing on those in relation to ethnic tribes. See Yao Weiyuan 姚薇元. Beichao huxing kao 北朝胡姓考. Wuhan: Wuhan University Press (2013). Hou Xudong 侯旭東 (2005) studied the institutional structure of these communities in order to examine the way all these patrons from diversified ethnic background 
can be accommodated. See Hou Xudong 侯旭東. Wu liu shiji beifang minzhong fojiao xinyang 五六世紀北方民眾佛教信仰. Beijing: Social Sciences Academic Press (2005).

${ }^{9}$ Nearly on all of these stelae, there was a section of patronage name list that elaborated the position of the lay patrons inside the communities. Syntactically speaking, the names of the patrons would be prefixed by their duties and titles. Hou Xudong 侯旭東 (1998) explored the structural organization of the local communities with reference to these names. See Hou Xudong 侯旭東. Beichao cunmin de shenghuo shijie 北朝村民的生活世界. Beijing: China Social Sciences Press (1998).

10 Religious professionals who offered spiritual and liturgical guidance in the communities presented a great complexity as it encompassed the titles from a large array of regional religious cults. Notably, the most frequent title was the religious master of the community (邑師 yishi). Buddhist religious titles were approached by scholars in an earlier stage that contributed to the formation of these patronage name list. Daoism, the native religion, further complicated the situation by introducing a completely different framework into the discussion. Zhang Zexun 張澤珣 (2009), in this sense, offered a detailed analysis of this aspect by mapping these titles back to the canonical scriptures. See Zhang Zexun 張澤珣. Bei wei guanzhong daojiao zaoxiangji yanjiu 北魏關中道教造像記研究. Macau: Macau University Press (2009), p. 76-85. Terry Kleeman (2016) in his recent work covered the roles of lay citizen and priest within the religious structures that offered new insights into the discussion of local communities. See Terry Kleeman. Celestial Masters: History and Ritual in Early Daoist Communities. Cambridge: Harvard University Asia Center (2016), p. 221-387.

11 Lay patrons normally called themselves as the member of the community (邑子 yizi), a term literally means the descendant of the community, showing the bloodline connection between them.

12 Excerpt from the Fumeng Wenqing Stele 夫蒙文慶造像碑, discovered in 1934 at Yao Province 耀縣, and now held at Yao Province Cultural Hall 耀縣文化館. See Wei Hongli 魏宏利. Bei wei guanzhong diqu zaoxiangji 北魏關中地區造像記. Beijing: China Social Science Press (2017), p. 77.

${ }^{13}$ Excerpt from the Zhang Qiandu Stele 張乾度造像碑. See Wei Hongli 魏宏利. Bei wei guanzhong diqu zaoxiangji 北魏關中地區造像記. Beijing: China Social Science Press (2017), p. 79.

${ }^{14}$ It is significant that those large scale artistic projects in the premodern period were usually done by professional craftsmen. Dunhuang cave temple can be regarded as a perfect example of this practice. Ma Changshou 馬長壽 (2017) in his recent work developed a significant depth into the craftsmen enlisted in the artistic project along the silk road. See Ma Changshou 馬長壽. Beiming suojian qian qin zhi suichu de guanzhong buzu 碑銘所見前秦至隋初的關中部族. Guilin: Guangxi Normal University Press (2006).

${ }^{15}$ Excerpt from the Wei Daojie Stele 魏道節造像碑, discovered in 1981 at Xuyang 徐陽, and now held at Lintong Museum 臨潼博物館. See Wei Hongli 魏宏利. Bei wei guanzhong diqu zaoxiangji 北魏關中地區造像記. Beijing: China Social Science Press (2017), p. 111.

${ }^{16}$ Epigraphical evidence has provided significant records of the spatial characteristic of the stelae. Wang Shenyue Stele 王神樂造像碑 (519 CE) indicated that the stele was placed on the side of the major road, as the original reads: to carve the stone for displaying the true appearance, to place the stele on the side of the road pathway. For tens of thousands of generations it will not fail, for thousands of years it will remain solid ( $「$ 刊石出真容，摄于路道邊 。萬代不可敗，千載而彌堅」). Furthermore, another example is the Qi Shuanghu Stele 錡雙胡 
造像碑 (520 CE) which indicated similar spatial location of the stele, as evidenced by the inscription: to place at the middle of the major crossroads, the whole community praise it with songs ( $「$ 安處路沖，高平顯唱」). Both stelae were huge in size, over a hundred centimeter, which marked their monumental perpendicular significance as the center of the community.

${ }^{17}$ Excerpt from the Yan Sengding Stele 晏僧定造像碑, discovered around 1980 at Yongshou Province 永壽縣, and now held at Yongshouxian Cultural Academy 永壽縣文化館. See Wei Hongli 魏宏利. Bei wei guanzhong diqu zaoxiangji 北魏關中地區造像記. Beijing: China Social Science Press (2017), p. 81-82.

18 Zhang Zexun 張澤珣 (2009) compiled considerable evidence that many stelae were established during significant liturgical dates. She observed that several of the stelae erected on relatively few dates of the uneven months. See Zhang Zexun 張澤珣. Bei wei guanzhong daojiao zaoxiangji yanjiu 北魏關中道教造像記研究. Macau: Macau University Press (2009), p. 36-38.

${ }^{19}$ Gil Raz (2012) argued that this was perhaps the scene of the earthly prison by referring to religious scriptures. Nevertheless, these entertainment scenes possessed a long trajectory in tomb arts even before the first century. By then, these scenes were the visual reproduction of the entertainment of the living for the deceased. But in our case, these scenes might be the snapshot of the bygone activities of the lay people in the community. Such an argument will be further elaborated in one of my forthcoming papers that conducts a detailed examination of the stele. See Gil Raz. The Emergence of Daoism: Creation of Tradition. New York: Routledge (2012), p. 210-256.

${ }^{20}$ Zhao Qiguang (1989) conducted a detailed study of dragon by tracing it back to the ancient mythological context. See Zhao Qiguang. Chinese Mythology in the Context of Hydraulic Society. Folklore Studies. Vol. 48, no. 2 (1989), p. 231-246. Michael Puett (2002) offered a systematic study of the ancient cosmological framework to relocate the position of sacrifice in a divinization trajectory. See Michael Puett. To Become a God: Cosmology, Sacrifice and SelfDivinization in Early China. Cambridge: Harvard University Press (2002), p. 201-224.

${ }^{21}$ See Qu Yuan 屈原. Songs of Chua 楚辭. Beijing: Chung Hwa Book Company (2013), p. 211.

22 See Dongfang Shuo 東方朔, Records of Ten Islands of the Inner Sea 海內十洲記, Daozang 道藏. Vol. 11. Beijing: Wenwu Press (1988). p. 53.

${ }^{23}$ See James Watt. The Giraffe as the Mythical Qilin in Chinese Art: A Painting and a Rank Badge in the Metropolitan Museum. Metropolitan Museum Journal. Vol. 43 (2008), p. 111. See also Eleanor Consten. The Deer in Early Chinese Art. Artibus Asiae. Vol. 26, no. $3 / 4$ (1963), p. 191-206.

${ }^{24} \mathrm{Li}$ Song 李松 (2002) proposed this interpretation in his early work. See Li Song 李淞. Chang'an yishu yu zongjiao wenming 長安藝術與宗教文明. Beijing: Chunghwa Book Company (2002), p. 465.

${ }^{25}$ Before the first century, dragon signalled the east, tiger the west, bird and deer the south and the north respectively. See Lillian Tseng. Funerary Spatiality: Wang Hui Sarcophagus in Han China. Anthropology and Aesthetics. No. 61/62. (2012), p. 118.

${ }^{26}$ Dorothy C. Wong (2004) in the monograph addressed the ethnic symbols created throughout the process of stele establishment. See Dorothy C. Wong. Chinese Steles: Pre-Buddhist and Buddhist Use of a Symbolic Form. Honolulu: University of Hawaii Press (2004), p. 71-88.

${ }^{27}$ It should be stated that the technique and equipment of fighting on horses was probably brought into the central plains by the nomadic people, but through a gradual process rather than any single conquest. See Owen Lattimore, Inner Asian Frontiers of China. Boston: Beacon Press (1962), p. 162-163. 
${ }^{28}$ Herrlee Creel (1965) successfully presented the three stages of horse employment in the late antiquity period. See Herrlee Creel. The Role of the Horse in Chinese History. The American Historical Review. Vol. 70, no. 3 (1965), p. 648-649.

${ }^{29}$ Erik Zürcher (2007) offered a brilliant foundation work in illustrating the transmission of the religion. See Erik Zürcher. The Buddhist Conquest of China. Leiden: Brill (2007), p. 18-80.

30 Livia Kohn (2008) built up a broad historical narrative that examined this phenomenon. Buddhism became the state religion of the northern kingdoms during the fifth and sixth centuries due to the support of the ethnic tribes. See Livia Kohn. Laughing at the Dao: Debates among Buddhists and Daoists in Medieval China. Magdalena: Three Pines Press (2008), p. 2223.

${ }^{31}$ Gavin Flood (1996) offered a general examination of the origin of this godly figure. See Gavin Flood. An Introduction to Hinduism. Cambridge: Cambridge University Press (1996), p. 174197. 